\title{
Resiliensi Trauma dan Gejala Posttraumatic Stress Disorder (PTSD) pada Dewasa Muda yang Pernah Terpapar Kekerasan
}

\section{Trauma Resilience and Posttraumatic Stress Disorder (PTSD)Symptoms in Violence-Exposed Young Adults}

\author{
Renada Gita Paramitha ${ }^{1}$, Chandradewi Kusristanti ${ }^{2}$ \\ ${ }^{1,2}$ Fakultas Psikologi Universitas YARSI, \\ Jl. Letjend Soeprapto Cempaka Putih, Jakarta Pusat, Indonesia
}

KATA KUNCI KEYWORDS

ABSTRAK

ABSTRACT
Trauma Resilience Scale (TRS), PTSD, Kekerasan, Dewasa muda Trauma Resilience Scale (TRS), PTSD, Violence, Young adults

Individu dewasa awal yang pernah terpapar kekerasan berisiko mengulangi kembali peristiwa kekerasan yang pernah mereka alami atau saksikan, mereka juga berisiko mengalami trauma yang berkembang menjadi PTSD (Posttraumatic Stress Disorder). Di sisi lain, individu yang resilien mampu menjaga fungsi fisik dan psikologisnya serta mampu beradaptasi secara positif setelah terpapar peristiwa traumatis. Penelitian ini bertujuan untuk menganalisis hubungan antara gejala PTSD dengan resiliensi terhadap trauma pada individu dewasa awal yang pernah terpapar kekerasan. Karakteristik penelitian ini adalah individu dewasa awal yang pernah terpapar kekerasan dan terindikasi mengalami gejala PTSD. Dalam penelitian ini, alat ukur PTSD Checklist - Civilian Version $(\alpha=0.969)$ digunakan untuk mengukur gejala PTSD dan alat ukur Trauma Resilience Scale $(\alpha=0.974)$ digunakan untuk mengukur resiliensi terhadap trauma. Pengujian menggunakan Pearson Product Moment menemukan adanya korelasi signifikan antara gejala PTSD dengan resiliensi terhadap trauma $(p<0.01$, $r=-.564)$ pada partisipan $(n=131)$. Hasil penelitian ini menunjukkan pentingnya bagi institusi ataupun praktisi yang berminat dalam pemulihan trauma untuk mulai mengembangkan program intervensi yang berfokus pada peningkatan resiliensi trauma bagi penyintas kekerasan.

Young adults who've been exposed to violence risk repeating the violence they have experienced or witness. They are also at risk of experiencing trauma that develops into PTSD (Posttraumatic Stress Disorder). On the other hand, resilient individuals are able to maintain their physical and psychological functions and are able to adapt positively after exposure to traumatic events. This study aims 


\begin{abstract}
to investigate the relationship between PTSD symptoms and resilience to trauma in young adults who have been exposed to violence. Characteristics of participants were young adults who had been exposed to violence and showed PTSD symptoms. In this study, PTSD Checklist - Civilian Version was used to measure PTSD symptoms and Trauma Resilience Scale was used to measure trauma resilience. Using Pearson Product Moment, it showed a significant correlation between PTSD symptoms and trauma resilience ( $p<0.01, r$ $=-.564)$ in participants $(n=131)$. Results of this study indicate the importance of institutions or practitioners interested in trauma recovery to begin developing intervention programs that focus on increasing trauma resilience for violence survivors.
\end{abstract}

\section{PENDAHULUAN}

Peristiwa traumatis merupakan peristiwa yang luar biasa, bukan karena sesuatu yang jarang terjadi, namun terkait dengan korban yang harus melakukan adaptasi tidak biasa terhadap kehidupannya (Herman \& Harvey, 1997). Kekerasan merupakan salah satu bentuk peristiwa traumatis (Cortina \& Kubiak, 2006). Di Indonesia, jumlah kasus kekerasan terus meningkat setiap tahunnya. Kasus kekerasan yang terjadi tersebut bervariasi, mulai dari kekerasan personal (misalnya kekerasan dalam rumah tangga dan kekerasan dalam pacaran), kekerasan komunitas (misalnya perkosaan dan pencabulan), ataupun kekerasan berbasis gender (Putra, 2017). Menurut APA (American Psychological Association), kekerasan didefinisikan sebagai bentuk ekstrim dari agresi, yang berwujud penyerangan, pemerkosaan, ataupun pembunuhan (apa.org, 2000).

Margolin dan Gordis (2004) membagi jenis kekerasan menjadi family violence dan community violence. Family violence merupakan kekerasan yang dilakukan oleh orang terdekat, seperti oleh keluarga, sedangkan community violence merupakan kekerasan yang dilakukan oleh orang di luar keluarga atau orang yang tidak dikenal. Terkait dampak kekerasan, Madsen dan
Abell (2010) menyatakan bahwa individu yang menyaksikan ataupun mengalami langsung suatu peristiwa kekerasan akan mengalami efek traumatis yang relatif sama.

Di usia dewasa awal, individu yang pernah menyaksikan atau mengalami langsung peristiwa kekerasan mengalami banyak efek negatif dari peristiwa tersebut. Mereka dapat mengalami kesulitan dalam menjalin relasi romantis (Finkelhor \& Browne, 1985), menampilkan perilaku berisiko seperti merokok, minum minuman keras, menggunakan obatobatan terlarang, hingga mengalami stres (Papalia \& Feldman, 2014), melakukan kekerasan terhadap pasangannya ataupun diperlakukan secara kasar oleh pasangannya (Ehrensaft, Cohen, Brown, Smailes, Chen, \& Johnson, 2003). Efek lainnya dari peristiwa kekerasan yang terjadi adalah trauma yang dialami individu (de Zulueta, 2007).

Kekerasan berada di luar keinginan korbannya dan membuat mereka harus mengalami penderitaan yang mendalam, sehingga peristiwa kekerasan dikatakan sebagai peristiwa traumatis (Norris, 1992). Jenis dan tingkat keterpaparan terhadap peristiwa traumatis dapat menjadi salah satu 
faktor kerentanan individu terhadap berkembangnya PTSD (Posttraumatic Stress Disorder) (Cusack, Falsetti, \& de Arellano, 2003; Pimlott-Kubiak \& Cortina, 2003; Saxe \& Wolfe, 1999; Wolfe \& Kimerling, 1997; dalam Cortina \& Pimlott-Kubiak, 2006). Norris (1992) menemukan individu dewasa awal yang pernah terpapar kekerasan memiliki gejala PTSD (Post Traumatic Stress Disorder) yang paling tinggi dibandingkan dengan individu pada tahap usia dewasa lainnya. Gejala PTSD didefinisikan sebagai munculnya gangguan pada individu sebagai reaksi alamiah individu yang melihat, atau mengalami langsung suatu peristiwa traumatis (APA, 1994; Stamm, 1999; Javidi \& Yadollahie, 2012). Gejala PTSD tersebut dipengaruhi oleh beberapa faktor, seperti usia keterpaparan individu (Brailey, Vasterling, Proctor, Constans, \& Friedman, 2007), treatment yang dijalani (Hoge, Eloise, Austin, Mark, \& Pollack, 2007), pendidikan (Engelhard, Hout, \& Schouten, 2006) dan gender (Johnson \& Thompson, 2008).

Walaupun peristiwa traumatis seperti kekerasan dapat meningkatkan resiko individu untuk mengalami gangguan kejiwaan seperti PTSD, nyatanya penelitian-penelitian yang ada menemukan bahwa banyak individu yang dapat beradaptasi secara positif meskipun mereka pernah terpapar peristiwa traumatis. Penelitian Alim, dkk (2008) menemukan beberapa individu yang pernah terpapar peristiwa traumatis tidak mengalami PTSD seumur hidupnya. Proses yang dinamis dimana individu dapat menampilkan adaptasi positif meski mengalami kesulitan atau trauma yang signifikan disebut sebagai resiliensi (Luthar, Cicchetti, \& Becker, 2000). Oleh Madsen dan Abell (2010), resiliensi trauma dikonseptualisasikan sebagai suatu fenomena yang memban- tu individu untuk dapat berfungsi kembali setelah mengalami peristiwa atau kejadian traumatis. Kemampuan untuk menemukan hubungan yang mendukung di luar keluarga dan harga diri (Valentine \& Feinauer, 1993), gender (Banyard \& Cantor, 2004), dan jumlah paparan terhadap peristiwa traumatis (Ungar, 2013) merupakan faktor-faktor yang dapat mempengaruhi resiliensi individu dalam menyikapi suatu peristiwa traumatis, termasuk kekerasan.

Berdasarkan tinjauan literatur yang peneliti lakukan, belum banyak penelitian yang menginvestigasi tentang resiliensi trauma dan gejala PTSD pada konteks kekerasan, baik sebagai penyintas ataupun saksi peristiwa suatu kekerasan. Penelitian sebelumnya terkait dengan gejala PTSD dan resiliensi yang dilakukan oleh Connor (2003) tidak spesifik dilakukan terhadap subjek berupa individu dewasa awal yang pernah terpapar kekerasan sebagai sampel. Meski demikian, penelitian tersebut mengungkapkan tingkat resiliensi berhubungan negatif secara signifikan dengan gejala PTSD yang dimiliki individu. Penelitian yang dilakukan oleh Blain, Galovski, Elwood, dan Meriac (2013) terkait gejala PTSD pada penyintas kekerasan seksual mengungkapkan tentang reaksi emosional penyintas yang dapat mempengaruhi gejala PTSD yang dialami. Penelitian tersebut mengungkapkan bahwa reaksi emosional yang negatif, seperti rasa bersalah, rasa malu, keputusasaan, kemarahan, dan kesedihan berkaitan dengan reaksi menyalahkan diri sendiri yang pada akhirnya dapat menyebabkan tingkat gejala PTSD pada individu meningkat.

Mengacu pada meningkatnya angka kekerasan saat ini dan risiko bagi individu dewasa awal untuk mengalami kembali peristiwa kekerasan yang pernah mereka alami atau saksikan, 
baik sebagai korban ataupun pelaku, maka penelitian ini bertujuan untuk menganalisis hubungan antara gejala PTSD dengan resiliensi terhadap trauma pada individu dewasa awal yang pernah terpapar kekerasan. Jika penelitian ini membuktikan bahwa gejala PTSD berhubungan signifikan dengan resili-

\section{METODE PENELITIAN}

Penelitian ini bertujuan untuk menganalisis hubungan antara gejala PTSD dan resiliensi terhadap trauma pada individu dewasa awal yang pernah terpapar kekerasan. Dengan demikian, karakteristik partisipan ini adalah individu berusia 20 hingga 40 tahun yang pernah mengalami ataupun menyaksikan peristiwa kekerasan. Karakteristik lainnya adalah partisipan harus terindikasi gejala PTSD, yang dilihat dari skor $\geq 50$ pada alat ukur PTSD ChecklistCivilian Version. Dengan menggunakan metode purposive sampling, partisipan dalam penelitian ini berjumlah 131 orang.

Penelitian ini menggunakan dua kuesioner. Gejala PTSD diukur menggunakan alat ukur PTSD Checklist-Civilian Version (PCL-C) yang disusun oleh Weathers, Litz, Huska, dan Keane (1993), sedangkan resiliensi terhadap trauma diukur menggunakan alat ukur Trauma Resilience Scale (TRS) yang disusun oleh Madsen dan Abell (2010). Setelah dilakukan uji coba terhadap 41 orang sampel yang sesuai dengan kriteria penelitian, ditemukan bahwa kedua alat ukur tersebut reliabel untuk digunakan $(\alpha>0.6)$. Hasil analisis aitem untuk seluruh aitem pada kedua alat ukur tersebut juga menunjukkan bahwa aitem-aitem pada alat ukur tersebut valid untuk digunakan (skor corrected item-total correlation berada pada rentang $0.281-0.918$ ).

Data yang didapatkan dari kedua alat ukur tersebut kemudian peneliti ensi trauma, maka hasil ini diharapkan dapat menjadi dasar bagi para praktisi maupun institusi terkait untuk merancang suatu program yang dapat meningkatkan kesadaran masyarakat mengenai pentingnya melakukan tindakan preventif serta penanganan terhadap peristiwa kekerasan di Indonesia.

olah menggunakan teknik KolmogorovSmirnov guna mengetahui distribusi data penelitian. Jika data penelitian terdistribusi normal $(\mathrm{p}>0.05)$, maka peneliti akan melakukan uji korelasi parametrik menggunakan Pearson Product Moment. Sebaliknya, apabila data penelitian tidak terdistribusi normal $(\mathrm{p}<$ 0.05), maka peneliti akan melakukan pengujian korelasi dengan menggunakan Spearman's Rank.

$$
\text { Selain alat ukur PCL-C dan }
$$

TRS, untuk memperkaya hasil penelitian, peneliti juga menyusun kuesioner riwayat kekerasan yang bertujuan untuk menggali tentang gambaran peristiwa kekerasan yang partisipan alami atau saksikan. Kuesioner tersebut disusun peneliti dengan mengacu pada literatur mengenai kekerasan. Margolin dan Gordis (2004) mengungkapkan bahwa bahwa dampak yang individu rasakan setelah peristiwa kekerasan tergantung pada waktu, jenis, dan keparahan paparan kekerasan tersebut. Kemudian, Ungar (2013) memaparkan bahwa berbagai faktor yang ada di lingkungan individu dapat mempengaruhi resiliensi individu. Dengan demikian, peneliti menyusun aitem pada kuesioner riwayat kekerasan dengan pertanyaan berupa pendidikan dan gender partisipan; jenis dan durasi kekerasan; dan lain sebagainya. Selanjutnya, data yang diperoleh dari kuesioner riwayat kekerasan ini akan dimanfaatkan sebagai analisis tambahan dalam penelitian ini. Analisis tambahan 
terhadap data demografi menggunakan

ANOVA.

Independent Sample T-Test dan One-

\section{ANALISIS DAN HASIL}

Hasil perhitungan korelasi yang dilakukan menggunakan Pearson Product Moment menunjukkan adanya korelasi signifikan antara gejala PTSD dengan resiliensi terhadap trauma $(p<0.01, r=-.564 * *)$. Dengan kata lain, hipotesis utama penelitian ini diterima. Hasil uji korelasi tersebut ditunjukkan dalam Tabel 1 di bawah ini:

Tabel 1. Hasil Analisis Utama

\begin{tabular}{lll}
\hline \multicolumn{2}{c}{ Gejala PTSD } \\
\hline \multirow{2}{*}{ Resiliensi Trauma } & Koefisien korelasi & $-0.564^{* *}$ \\
\cline { 2 - 3 } & Signifikansi & 0.000 \\
\hline
\end{tabular}

$* * \mathrm{p}<0.01$

Selanjutnya, peneliti melakukan uji analisis tambahan dengan memanfaatkan data demografi partisipan. Analisis tambahan pada variabel demografi berdasarkan data pada kuesioner riwayat kekerasan menunjukkan adanya perbedaan skor yang signifikan ( $\mathrm{p}<$ 0.05) pada gejala PTSD partisipan berdasarkan pengalaman kekerasan dan keberlangsungan kekerasan. Pada resiliensi terhadap trauma, ditemukan adanya perbedaan skor yang signifikan $(\mathrm{p}<0.05)$ jika ditinjau dari pengalaman terpapar kekerasan dan keberlangsungan kekerasan. Hasil uji beda tersebut dapat dilihat pada Tabel 2 di bawah ini:

Tabel 2. Hasil Analisis Tambahan

\begin{tabular}{ccc}
\hline Data Demografi & Gejala PTSD & $\begin{array}{c}\text { Resiliensi } \\
\text { Trauma }\end{array}$ \\
\hline Jenis kelamin & .339 & .319 \\
Pendidikan & .110 & .590 \\
\cline { 2 - 3 } Pengalaman kekerasan & $.000^{* *}$ & $.000^{* *}$ \\
\cline { 2 - 3 } Usia terpapar kekerasan & .392 & .442 \\
\cline { 2 - 3 } Frekuensi terpapar kekerasan & .986 & .338 \\
Durasi terjadinya (tahun) & .724 & .274 \\
Keberlangsungan kekerasan & $.005^{* *}$ & $.007^{* *}$ \\
\cline { 2 - 3 } Treatment & .632 & .164 \\
\hline
\end{tabular}

$* * p<0.01$

Selanjutnya, uji statistik lanjutan menggunakan post-hoc Tukey menunjukkan bahwa rata-rata gejala PTSD secara signifikan lebih rendah pada partisipan yang pernah menyaksikan peristiwa kekerasan, $(\mathrm{M}=$ $60.77, \mathrm{SD}=5.812), \mathrm{F}(3.424)=8.248$, $\mathrm{p}>.001$ dibandingkan dengan partisipan yang pernah mengalami langsung $(\mathrm{M}=67.38, \mathrm{SD}=6.614), \mathrm{F}$ $(6.605)=8.248, \mathrm{p}<.001$ ataupun pernah mengalami dan menyaksikan (M $=63.96, \mathrm{SD}=6.403), \mathrm{F}(3.181)=$ $8.248,>.001$. Sementara itu, uji 
statistik menggunakan t-test menunjukkan bahwa partisipan yang hingga saat pengisian kuesioner penelitian masih terpapar kekerasan menunjukkan gejala PTSD yang lebih tinggi dibandingkan dengan partisipan yang saat itu sudah tidak terpapar kekerasan, $\mathrm{t}(2.873)=2,873, \mathrm{p}>.001$.

Pada variabel resiliensi terhadap trauma, hasil uji statistik menggunakan post-hoc Tukey menunjukkan bahwa rata-rata resiliensi terhadap trauma secara signifikan ditemukan lebih rendah pada partisipan yang mengalami langsung peristiwa kekerasan $(\mathrm{M}=$ 157.62, $\mathrm{SD}=41.394), \mathrm{F}(19.446)=$

\section{DISKUSI}

Penelitian ini mengimplikasikan bahwa semakin minim gejala PTSD yang dimiliki partisipan, maka ia semakin mampu resilien terhadap trauma, dan sebaliknya. Hasil penelitian ini sejalan dengan hasil penelitian sebelumnya yang dilakukan oleh Connor, dkk (2003), yang menemukan bahwa tingkat resiliensi berhubungan negatif secara signifikan dengan tingkat keparahan gejala PTSD. Selain itu, Bonanno (2004) juga menemukan bahwa individu yang resilien lebih mampu untuk mempertahankan tingkat fungsi fisik dan psikologis yang relatif sehat dan stabil setelah adanya pengalaman traumatis. Dengan demikian, semakin tinggi resiliensi trauma yang dimiliki individu berkaitan dengan minimnya gejala PTSD yang dimiliki individu.

Hasil penelitian ini juga sejalan dengan hasil penelitian Campbell-Sills, dkk (2006) yang menemukan bahwa individu dengan tingkat resiliensi yang tinggi memiliki gejala gangguan kejiwaan yang lebih sedikit dibandingkan individu dengan tingkat resiliensi yang rendah. Tingkat gejala PTSD itu sendiri berhubungan kuat dengan gangguan kejiwaan lainnya
8.473, $\mathrm{p}>.001$ dibandingkan partisipan yang menyaksikan $(\mathrm{M}=204.13, \mathrm{SD}=$ 48.537), $\mathrm{F}(46.508)=8.473, \mathrm{p}<.001$ ataupun pernah mengalami maupun menyaksikan peristiwa kekerasan $(\mathrm{M}=$ 177.07, $\mathrm{SD}=42.553), \mathrm{F}(27.061)=$ $8.473, \mathrm{p}>.001$. Sementara itu, uji statistik menggunakan t-test menemukan bahwa partisipan yang saat pengisian kuesioner sudah tidak lagi terpapar kekerasan memiliki skor yang lebih tinggi pada variabel resiliensi trauma dibandingkan partisipan yang saat itu masih terpapar kekerasan, $t$ $(2.964)=2.731, \mathrm{p}>.001$.

pada individu (Javidi \& Yadollahie, 2012). Gejala PTSD yang tinggi dapat mengakibatkan individu mengalami gangguan stres pasca trauma, tingkat intrusi dan penghindaran yang tinggi, serta gejala depresi atau kecemasan (Brewin, Andrews, \& Valentine, 2000). Namun, seiring dengan resiliensi terhadap trauma yang meningkat, maka tingkat gejala PTSD yang dapat menyebabkan individu mengalami gangguan kejiwaan menjadi menurun.

Pada penelitian ini, peneliti menggambarkan faktor-faktor yang mungkin mempengaruhi dampak dari peristiwa kekerasan pada partisipan. Hasil uji statistik terhadap data demografi dan kuesioner riwayat kekerasan penelitian menunjukkan bahwa partisipan yang pernah mengalami langsung peristiwa kekerasan memiliki gejala PTSD yang lebih tinggi dibandingkan partisipan yang hanya menyaksikan peristiwa kekerasan. Hasil ini sejalan dengan temuan Spilsbury, dkk (2007) bahwa individu yang mengalami atau menjadi korban langsung dari peristiwa kekerasan memiliki tingkat trauma yang terus meningkat, dibandingkan dengan 
individu yang hanya menyaksikan peristiwa kekerasan. Spilsbury, dkk (2007) menemukan bahwa individu yang mengalami langsung peristiwa kekerasan memiliki persepsi dan ketakutan bahwa kekerasan yang pernah mereka alami akan terjadi kembali.

Hasil lain penelitian ini adalah partisipan yang masih terpapar kekerasan memiliki gejala PTSD yang lebih tinggi dibandingkan dengan partisipan yang sudah tidak lagi terpapar kekerasan. Pada penelitian sebelumnya, Ferrada-Noli, Asberg, dan Ormstad (1998) menemukan individu yang masih terpapar kekerasan mengalami trauma yang beberapa di antaranya terwujud dalam keinginan bunuh diri, mimpi buruk, mengurangi atau mengabaikan kontak sosial, dan merasa pesimis tentang masa depan. Tingkat trauma yang tinggi dapat menjadi faktor utama yang mempengaruhi pengembangan PTSD (Frans, Rimmo, Aberg, \& Fredrikson, 2005). Intensitas dan frekuensi trauma yang terus menerus dapat memberikan kontribusi terhadap pengembangan PTSD individu (Frans, dkk., 2005). Oleh karena itu, partisipan yang masih terpapar kekerasan memiliki gejala PTSD yang terus meningkat daripada partisipan yang sudah tidak terpapar kekerasan.

Resiliensi ditemukan beragam pada masing-masing individu dalam satu populasi karena adanya variasi individu, konteks, dan budaya (Ungar, 2013). Dalam penelitian ini ditemukan bahwa partisipan yang pernah menyaksikan peristiwa kekerasan memiliki resiliensi trauma yang lebih tinggi dibandingkan dengan partisipan yang mengalami atau menjadi korban

\section{KESIMPULAN}

Hasil utama penelitian ini mengimplikasikan adanya hubungan langsung dari peristiwa kekerasan. Individu mempersepsikan bahwa mengalami peristiwa kekerasan atau mengalami dan menyaksikannya sekaligus lebih negatif dibandingkan hanya menyaksikan peristiwa kekerasan (McClosky dkk, 1995; dalam Edleson, 1999). Hal tersebut dapat menjelaskan temuan penelitian ini bahwa partisipan yang memiliki pengalaman menyaksikan peristiwa traumatis memiliki resiliensi yang lebih tinggi dibandingkan dengan individu yang mengalami langsung suatu peristiwa traumatis berupa kekerasan.

Kemampuan penelitian ini dalam mengungkapkan faktor-faktor yang dapat mempengaruhi gejala PTSD dan resiliensi terhadap trauma melalui uji statistik terhadap data demografi sebagai analisis tambahan merupakan salah satu kelebihan penelitian ini. Selain itu, karakteristik sampel dalam penelitian ini yang spesifik kepada individu yang pernah terpapar peristiwa traumatis berupa kekerasan juga merupakan kekuatan penelitian ini, karena belum banyak penelitian di bidang psikologi terkait kasus kekerasan di Indonesia. Di sisi lain, terdapat sejumlah kelemahan dalam penelitian ini. Dengan pertimbangan jumlah aitem, penelitian ini tidak mengukur faktor-faktor lain yang diduga berhubungan dengan resiliensi trauma ataupun gejala PTSD pada partisipan, seperti locus of control, atribusi sosial, ataupun social learning. Selain itu, penelitian ini juga tidak spesifik meneliti dalam konteks salah satu jenis kekerasan, sehingga hasil penelitian ini tidak dapat mengungkap dinamika pada populasi spesifik terkait jenis kekerasan yang dialami atau disaksikan.

negatif yang signifikan antara gejala PTSD dengan resiliensi terhadap trauma 
pada individu dewasa awal yang pernah terpapar kekerasan. Semakin minim gejala PTSD yang dimiliki partisipan, maka ia semakin mampu resilien terhadap trauma, dan sebaliknya. Selanjutnya, analisis tambahan dari penelitian

\section{SARAN}

Mengacu pada hasil utama penelitian ini, yang mengungkapkan hubungan negatif yang signifikan antara gejala PTSD dengan resiliensi terhadap trauma, maka bagi para praktisi atau institusi yang berminat di bidang pemulihan penyintas kekerasan dapat merancang suatu kegiatan yang bertujuan untuk meningkatkan resiliensi terhadap trauma pada penyintas kekerasan sebagai upaya proteksi terhadap pengembangan gejala PTSD. Salah satu kelemahan penelitian ini adalah penelitian ini tidak spesifik menginvestigasi dalam konteks jenis kekerasan tertentu, sehingga hasil penelitian ini tidak dapat mengungkap dinamika suatu kekerasan secara ini menunjukkan bahwa terdapat perbedaan yang signifikan pada gejala PTSD maupun resiliensi trauma partisipan jika ditinjau dari pengalaman kekerasan dan keberlangsungan kekerasan yang dialami ataupun disaksikan partisipan.

spesifik. Sebagai contoh, berdasarkan literatur yang ada, kekerasan seksual memiliki dampak yang paling besar dibandingkan dengan jenis kekerasan lainnya. Oleh karena itu, untuk penelitian selanjutnya, peneliti berharap karakteristik sampel dapat menjadi lebih spesifik pada konteks salah satu jenis kekerasan, misalnya kekerasan seksual. Penelitian selanjutnya juga diharapkan dapat meneliti variabelvariabel lain yang tidak dijelaskan oleh penelitian ini, seperti variabel locus of control dan atribusi sosial untuk menjelaskan resiliensi trauma secara lebih komprehensif ataupun variabel social learning untuk lebih menggambarkan gejala PTSD partisipan.

\section{DAFTAR PUSTAKA}

Alim, T. N., Feder, A., dkk. (2008). Trauma, resilience, and recovery in a high-risk african-american population. The American Journal of Psychiatry, 165(12). Diperoleh pada 10 Februari 2018 dari https://ajp.psychiatryonline.org/ doi/abs/10.1176/appi.ajp.2008.0 $\underline{7121939}$

American Psychiatric Association. (2013). Diagnostic And Statistical Manual of Mental Disorder Edition "DSM 5". Washington DC: American Psychiatric Publishing. Washington DC.
American Psychological Association. Violence. Diperoleh pada 10 Februari 2018 dari http://www.apa.org/topics/viole nce/index.aspx

Banyard, V. L. \& Cantor, E. N. (2004). Adjustment to college among trauma survivors: An exploratory study of resilience. Journal of College Student Development, 45, 207 - 221.

Blain, L. M., Galovski, T. E., Elwood, L. S., \& Meriac, J. P. (2013). How does the posttraumatic cognitions inventory fit in a four-factor posttraumatic stress disorder world? An initial analy- 
sis. Psychological Trauma: Theory, Research, Practice, and Policy, 5 (6), $513-520$. How does the posttraumatic cognitions inventory fit in a four-factor posttraumatic stress disorder world? An initial analysis. Psychological Trauma: Theory, Research, Practice, and Policy, 5(6), 513520.

http://dx.doi.org/10.1037/a0030 $\underline{251}$

Bonanno, G. A., Papa, A., Lalande, K., Westphal, M., \& Coifman, K. (2004). The importance of being flexible: the ability to both enhance and suppress emotional expression predicts long-term adjustment. Psychological Science, 15(7), 482-487. Diperoleh pada 10 Februari 2018 dari http://journals.sagepub. com/doi/abs/10.1111/j.09567976.2004.00705.x

Bonanno, G. A. (2004). Loss, trauma, and human resilience: have we underestimated the human capacity to thrive after extremely aversive events? American Psychologist, 59, 20-22.

Bonanno, G. A., \& Mancini, A. D. (2012). Beyond resilience and PTSD: mapping the heterogeneity of responses to potential trauma. Psychological Trauma: Theory, Research, Practice, and Policy, Vol. 4, No. 1.

Brailey, K., Vasterling, J. J., Proctor, S. P., Constans, J.I., Friedman, M. J. (2007). PTSD symptoms, life events, and unit cohesion in u.s. soldiers: baseline findings from the neurocognition deployment health study. Journal of Traumatic Stress, 20(4).
Brewin, C. R., Andrews, B., \& Valentine, J. D. (2000). Metaanalysis of risk factors for posttraumatic stress disorder in trauma-exposed adults. Journal of Consulting and Clinical Psychology, 68, 748 - 766.

Campbell-Sills, L., Cohan, S. L., \& Stein, M. B. (2006). Relationship of resilience to personality, coping, and psychiatric symptoms in young adults. Behaviour Research and Therapy, 44(4)

Connor, K. M. (2006). Assessment of resilience in the aftermath of trauma. Journal of Clinical Psychiatry, 67(2), 46-49

Connor, K. M., Sutherland, S. M., Tupler, L. A., Malik, M. L., \& Davidson, J. R. (1999). Fluoxetine in post-traumatic stress disorder: randomised, double-blind study. The British Journal of Psychiatry, 175(1), 17-22.

Cortina, L. M., \& Kubiak, S. P. (2006). Gender and posttraumatic stress: sexual violence as an explanation for women's increased risk. Journal of Abnormal Psychology, 11(4). Diperoleh pada 10 Februari 2018 dari http://psycnet.apa.org/record/20 06-20696-010।

De Zulueta, F. (2007). From Pain to Violence: The Traumatic Roots of Destructiveness (2nd ed.). New Jersey: Wiley.

Edleson, J. L. (1999). Children's witnessing of adult domestic violence. Journal of Interpersonal Violence, 14.

Ehrensaft, M. K., Cohen, P., Brown, J., Smailes, E., Chen, H. \& Johnson, J. G. (2003). Intergenerational transmission of partner violence: A 20-year 
prospective study. Journal of Consulting and Clinical Psychology, 71 (4), 741 - 753.

Engelhard, M., Hout, M., \& Schouten, E.G.W. (2006). Neuroticism and low educational level predict the risk of posttraumatic stress disorder in women after miscarriage or stillbirth. General Hospital Psychiatry, 28(5), 414417. Diakses pada 11 Februari 2018 dari https://www.sciencedirect.com/s cience/article/pii/S01638343060 $\underline{01253}$

Ferrada-Noli, M., Asberg, M., Ormstad, K., Lundin, T., \& Sundbom, E. (1998). Suicidal behavior after severe trauma. part 1: ptsd diagnoses, psychiatric comorbidity, and assessments of suicidal behavior. Journal of Traumatic Stress, 11(1), 103-111.

Ferrada-Noli, M., Asberg, M., Ormstad, K., Lundin, T., \& Sundbom, E. (1998). Suicidal behavior after severe trauma. part 2: the association between methods of torture and of suicidal ideation in posttraumatic stress disorder. Journal of Traumatic Stress, 11(1), 113-124.

Finkelhor, D. \& Browne, A. (1985). The traumatic impact of child sexual abuse: A conceptualization. American Journal of Orthopsychiatry, 55, $530-541$.

Frans, O., Rimmo, P. A., Aberg, L., \& Fredrikson, M. (2005). Trauma exposure and post-traumatic stress disorder in the general population. Acta Psychiatrica Scandinavica, 111(4), 291-299.

Herman, J.L. \& Harvey, M. R. (1997). Adult memories of childhood trauma: A naturalistic clinical study. Journal of Traumatic Stress, 10, $557-571$.

Hoge, E. A., Eloise, D., Austin, E. D., Mark, H., \& Pollack, M. D. (2007). Resilience: research evidence and conceptual considerations for posttraumatic stress disorder. Depression and Anxiety, 24.

Javidi, H., \& Yadollahie, M. (2012). Posttraumatic stress disorder (review). The International Journal of Occupational and Environmental Medicine, 3(1), 2-9.

Johnson, H., \& Thompson, A. (2007). The development and maintenance of post-traumatic stress disorder (PTSD) in civilian adult survivors of war trauma and torture: review. Clinical Psychology Review, 28, 36-47.

Madsen, M. D., \& Abell, N. (2010). Trauma resilience scale: validation of protective factors associated with adaptation following violence. Research on Social Work Practice, 20(2), 223-233.

Margolin, G., \& Gordis, E. B. (2015). Children's exposure to violence in the family and community. American Psychological Society, 13(4), 152-155.

Margolin, G., \& Gordis, E.B. (2003). Co-occurrence between marital aggression and parents' child abuse potential: The impact of cumulative stress. Journal of $\mathrm{Vi}$ olence and Victims, 18.

Norris, F. H. (1992). Epidemiology of trauma: Frequency and impact of different potentially traumatic events on different demographic groups. Journal of Consulting 
and Clinical Psychology, 60, $409-418$.

Luthar S. S., Cicchetti, D., \& Becker, B. (2000). The construct of resilience: a critical evaluation and guidelines for future work. Journal of Child Development, 7(3). Diperoleh pada 10 Februari 2018 dari http://onlinelibrary.wiley.com/g etIdenti-

tyKey?redirectTo=http $\% 3 \mathrm{~A} \% 2 \mathrm{~F}$ $\% 2$ Fonlinelibrary.wiley.com

Papalia, D. E., \& Feldman, R. D. (2014). Menyelami Perkembangan Manusia Edisi 2. Jakarta Selatan: McGraw-Hill Education dan Salemba Empat.

Putra, L. M. (2017). 2016, Ada 259.150 Kasus Kekerasan Terhadap Perempuan. Diakses pada 12 Februari 2018 dari https://nasional.kompas.com/rea d/2017/03/07/19240821/2016.ad a.259.150.kasus.kekerasan.terha dap.perempuan

Spilsbury, J.C., Belliston, L., Drotar, D., Drinkard, A., Kretschmar, J.,
Creeden, R., Flannery, D. J. \& Friedman, S. (2007). Clinically significant trauma symptoms and behavioral problems in a community-based sample of children exposed to domestic violence. Journal of Family Violence, 22 (6), 487 - 499.

Ungar, M. (2013). Resilience, trauma, context, and culture. Trauma, Violence, \& Abuse, 14 (3), 254 266.

Valentine, L. \& Feinauer, L. L. (1993). Resilience factors associated with female survivors of childhood sexual abuse. The American Journal of Family Therapy, 21(3).

Weathers, F. W., Litz, B. T., Herman, D.S., Huska, J. A. \& Keane, T. M. (1993). The PTSD checklist: Reliability, validity, and diagnostic utility. Annual Convention of the International Society for Traumatic Stress Studies, 462. 